\title{
RUANG EDUKASI HUTAN DI KALIMANTAN
}

\author{
Anugerah Bagus Wicaksono1), Nina Carina ${ }^{2)}$ \\ 1)Program Studi S1 Arsitektur, Fakultas Teknik, Universitas Tarumanagara, anugerahbagus4@gmail.com \\ 2) Program Studi S1 Arsitektur, Fakultas Teknik, Universitas Tarumanagara, ninac@ft.untar.ac.id
}

Masuk: 04-07-2021, revisi: 15-08-2021, diterima untuk diterbitkan: 23-10-2021

\begin{abstract}
Abstrak
Kebakaran hutan, penebangan liar dan penyalahgunaaan lahan atau dengan sebutan deforestasi di Kalimantan sudah sering terjadi. Salah satu contoh adalah kebakaran hutan yang sangat besar di Kalimantan Tengah, lahan hutan diubah menjadi kebun kelapa sawit. Munculnya hewan liar di lahan pemukiman terjadi karena tidak adanya keseimbangan antara manusia, hewan dan alam yang membuat rusaknya pola aktivitas dan tempat tinggal baik di pemukiman manusia ataupun hewan di alam liar. Arsitektur tidak bisa mengabaikan kejadian yang terus menerus terjadi. Proyek ini bertujuan mengubah pola pikir akan pentingnya sebuah keseimbangan antara manusia, hewan, dan alam dengan cara membuat sebuah tempat yang bisa merefleksikan alam. Melalui Ruang Edukasi Hutan Kalimantan Tengah diharapkan tercipta sebuah ruang yang mengkoneksikan kehidupan di hutan dan di kota dengan membagi aktivitas berdasarkan ruang sehingga bisa membuat sebuah rasa kebersamaan dan muncul keseimbangan di antara makhluk hidup.
\end{abstract}

Kata kunci: deforestasi; Kalimantan; keseimbangan; ruang edukasi hutan

\begin{abstract}
Forest fires, illegal logging, and land use or deforestation in Kalimantan are common. One example of a fire is a very large forest in Central Kalimantan, forest land being converted into oil palm plantations. The emergence of liar animals in residential areas occurs because there is no balance between humans, animals, and nature which causes damage to patterns of activity and residence both in human settlements and animals in liars' nature. Architecture cannot ignore events that are constantly happening. This project aims to change the mindset of the importance of a balance between humans, animals, and nature by creating a place that can reflect nature. Through the Forest Education Spot in Central Kalimantan, it is hoped that there will be a space that connects life in the forest and in the city by dividing activities based on space to create a sense of togetherness and create a sense of togetherness balance between living things.
\end{abstract}

Keywords: balance; deforestation; forest education spot; Kalimantan

\section{Pendahuluan}

Hutan merupakan sumber daya alam yang menempati posisi strategis dalam kehidupan antara manusia dan hewan. Kawasan hutan di Indonesia sebagian besar adalah Kawasan dengan ekosistem yang sangat beragam dari hutan tropika, hutan rawa, dan hutan bakau. Dengan perkembangan kehidupan dari masa ke masa dalam menghadapi globalisasi serta proses industrialisasi dan modernisasi akan membuat sebuah perubahan sosial dalam sebuah kehidupan masyarakat, dan pada perubahan ini akan menimbulkan sebuah dampak yang besar pada kelangsungan hutan hutan di Indonesia sebagai sebuah penyangga hidup bagi manusia dan hewan. Karena hutan merupakan sebuah sumber daya alam yang sangat penting.

Dengan kondisi yang seperti ini, banyaknya penebangan liar yang terjadi bisa didefinisikan sebagai sebuah masalah sosial karena masyarakat sekarang hanya memikirkan sebuah prioritas yang mementingkan diri sendiri dengan keuntungan yang berjangka pendek dan berdampak Panjang terhadap lingkungan sekitar, dengan tidak memikirkan kepentingan makhluk hidup lainnya, seperti 
Hewan adalah makhluk hidup yang menempati lokasi bersama dengan makhluk hidup lainnya juga secara bersama-sama yang membentuk akan sebuah lingkungan.

\section{Rumusan Permasalahan}

- Bagaimana arsitektur membuat sebuah hubungan yang harmonis antara makhluk hidup dan alam.

- Bagaimana merancang sebuah fasilitas edukasi yang dapat menyadarkan orang tentang pentingnya menjaga hutan.

- Bagaimana membuat sebuah fasilitas edukasi yang memiliki nilai rekreatif tanpa merusak alam

\section{Tujuan dan Manfaat}

- Menciptakan ruang arsitektur yang bisa untuk berinteraksi langsung dengan kehidupan hutan.

- Membuat wadah edukasi yang bisa membuka mata dan hati manusia akan pentingnya hutan bagi kehidupan di bumi

- Mewadahi tempat rekreasi untuk mengedukasi masyarakat dan turis akan pentingnya masalah deforestasi.

- Menciptakan tempat untuk bisa menjaga dan melestarikan tanaman baik itu tanaman insitu maupun eksitu.

\section{KAJIAN LITERATUR}

\section{Definisi Ekologi}

Menurut G. Tyler Miller (1975) arti ekologi adalah ilmu yang mempelajari tentang sebuah hubungan timbal balik antara organisme dengan organisme lain beserta lingkungannya. Dan kata ekologi itu sendiri berasal dari dua kata dalam Bahasa Yunani, yaitu oikos dan logos. Oikos adalah tempat tinggal, dan logos adalah ilmu dan pengetahuan. Jadi ekologi adalah ilmu yang mempelajari sebuah organisme di tempat tinggalnya.

Pendekatan ekologi dalam arsitektur yang lain yaitu menurut Frick (1998) adalah bahwa ekoarsitektur mencakup keselarasan antara manusia dan alam. Eko-arsitektur mengandung juga dimensi waktu, alam, sosio kultural, ruang dan teknik bangunan. Dan disaat mempelajari tentang ekologi pasti akan mempelajari juga tentang ekosistem, bedasarkan struktur dan fungsi dari sebuah ekosistem, maka seseorang yang belajar ekologi harus didukung dengan pengetahuan yang relevan dengan kehidupannya. Bahwa belajar mengenai ekologi tidak hanya tentang ekosistem saja tetapi akan mempelajari organisme pada tingkatan yang lebih kecil seperti individu, populasi, dan komunitas.

\section{Pendekatan Hubungan Arsitektur dengan Perilaku Manusia}

Manusia membangun sebuah bangunan yang akan membentuk perilaku manusia tersebut. Dan setelah terbentuk dari sebuah bangunan yang dibuat, manusia Kembali membentuk arsitektur yang dibangun atas dasar perilaku yang sudah terbentuk. Untuk membentuk sebuah perilaku manusia bisa dipengaruhi oleh beberapa perancangan fisik ruang, seperti ukuran, bentuk, material, penataan, warna, suara, dan pencahayaan. Ada 4 pandangan yang bisa berhubungan dengan pengaruh desain arsitektur terhadap perilaku manusia:

- Pendekatan Kehendak Bebas (free-will Approach): Pendekatan ini berpendapat bahwa lingkungan tidak memiliki dampak apapun terhadap sebuah perilaku manusia.

- Determinisme Arsitektur (Architectural Determinism): Salah satu konsep awal dari pengaruh arsitektur terhadap perilaku. Istilah ini disebut sebagai determinisme lingkungan yang berarti bahwa lingkungan yang dibangun membentuk perilaku manusia di dalamnya. Dalam bentuknya yang paling ekstrim, arsitektur dan desain dipandang sebagai satu-satunya penyebab dari munculnya perilaku.

- Kemungkinan Lingkungan (Environmental Possibilsm) 
Lingkungan membuka kesempatan kepada perilaku manusia tetapi mansia tidak sepenuhnya bebas menentukan pilihannya. Karena setiap individu memiliki motivasi dan kompetensi yang paling tidak dipengaruhi oleh lingkungan alamiah, sosisal dan budaya. Hasil perilaku yang kita pilih akan ditentukan oleh lingkungan dan pilihan yang akan kita buat.

- Probabilisme Lingkungan (Environmental Probabilsm)

Pada konsep ini berasumsi bahwa sebuah organisme dapat memilih variasi respon pada berbagai situasi lingkungan dan pada saat itu muncul probabilitas yang berkaitan dengan perilaku yang lebih spesifik, seperti halnya pengaruh desain dan perilaku.

\section{Hal Yang Mempengaruhi Manusia}

Variabel fisik dan hal-hal yang mempengaruhi perilaku manusia terhadap bangunan arsitektur antara lain:

\section{- Ruang}

Pengaruh ruang terhadap perilaku manusia adalah sebuah perancangan fisik yang memiliki pengaruh terhadap perilakunya.

- Ukuran dan Bentuk

Ukuran dan bentuk harus disesuaikan dengan fungsi yang akan dibuat, karena sebuah ukuran yang besar dan kecil akan mempengaruhi psikologis dari pemakainya.

- Material dan Penataannya

Bentuk penataan dari material yang dibuat harus disesuaikan dengan sifat dari kegiatan yang ada di dalam ruang tersebut.

- Warna

Warna memiliki sebuah penan penting dalam mewujudkan suasana ruang untuk mewujudkan perilaku tertentu, tidak hanya menimbulkan suasana panas atau dingin tapi warna akan mempengaruhi kualitas dari ruang tersebut.

- Suara, Udara

Suara diukur dengan desibel, akan berpengaruh buruk bila terlalu keras. Demikian pula dengan temperatur dan pencahayaan yang dapat mempengaruhi psikologis seseorang.

\section{Kondisi Bumi Tanpa Hutan}

Negara Indonesia ini telah dihadapi kebarakan hutan, dan penebangan liar yang cukup dalam keadaan yang mengenaskan yang berdampak kepada satwa liar dan manusia juga. Jika keadaan seperti ini terus berlanjut maka tidak dipungkiri bahwa hutan akan bisa hilang dari bumi ini.

- Bumi akan kehilangan estetika hutan

Karena hutan adalah sebuah ciptaan dari tuhan yang memiliki seni alam yang sangat indah. Karena hutan bisa dijadikan sebagai tempat wisata alam atau untuk menenangkan diri dari kehidupan kota. Jika hutan hilang dari bumi ini, maka manusia tidak akan menemukan lagi tempat untuk menikmati keindahan alam yang ada di dalam hutan.

- Bumi akan kehilangan fungsi orologis hutan

Salah satu fungsi hutan yang paling penting adalah orologis yaitu untuk mencegah erosi. Jika hutan tidak ada dan ketika hujan deras terjadi maka banjir akan terjadi.

- Bumi akan kehilangan fungsi klimatologis hutan

Klimatologis adalah untuk mengatur sebuah suhu dan kelembaban udara agar stabil.

- Bumi akan kehilangan fungsi hidrologis hutan

Fungsi hidrologis yaitu berperan sebagai penyimpanan air. Jika tidak ada hutan maka bumi akan kehilangan sumber mata air dan akan mengalami kekeringan air yang sangat berdampak besar bagi kehidupan bumi. 


\section{METODE}

Metode perancangan yang digunakan dalam perancangan ini :

Tahap pengumpulan data.

Studi literatur

- Sebagai dasar teoritis untuk dasar konsep pemikiran

- Mengetahui dasar yang terkait untuk merancang desain

Studi preseden

- Sebagai pembanding proyek

- Mengerti standart yang dipakai proyek yang dijadikan sebagai preseden

Pengamatan lingkungan sekitar kawasan

- Lokasi: kawasan Kebun Raya Sampit

Metode pengamatan : a) pengamatan dari google maps, b) analisa kawasan

\section{Metode Desain Biophilic Design}

Penerapan biophilic design bukan hanya tentang membuat sebuah bangunan menjadi "hijau" dengan hanya memberikan tanaman di bangunan. Tetapi menurut Amjad Almusaed (2011), biophilic design adalah konsep yang mengusahakan untuk meminimalisir dampak negatif dari pemanasan yang ada di kehidupan perkotaan dalam skala mikro lokal yang memungkinkan manusia untuk dapat meningkatkan tingkat kenyamanan fisik dan improvisasi Kesehatan dari manusia itu sendiri.

Tujuan dari biophilic design adalah membuat sebuah ruang yang dapat memulihkan psikologis manusia, dan mensehatkan syaraf serta menghidupkan daya hidup yang estetik. Penerapan 14 pattern biophilic design pada sebuah ruangan sebagai berikut:

\section{- Visual connection with nature}

Sebuah pola yang tercipta dari indera pengheliatan dalam merasakan sebuah ruang yang berhubungan dengan alam baik secara langsung ataupun tidak langsung.

- Non-visual connection with nature

Pola yang mengandalkan indera pendengaran, pencium, peraba, dan perasa dalam merasakan ruang yang berhubungan dengan alam secara bersamaan.

- Non-rhytmic sensory stimuli

Pola ini berkaitan dengan alam yang bersifat tidak teratur yang membuat tidak sadar bagi pengguna ruang yang tetapi dapat menciptakan suasa ruang yang segar, dan menarik.

- Thermal and airflow variability

Pola ini berkaitan dengan sebuah pergerakan udara, suhu, dan kelembapan dengan sifat dinamis dan variasi pada ruangan yang bisa menyerupai kondisi asli di alam.

- Dynamic and diffuse lighting

Pola ini berkaitan dengan pergerakan cahaya alami karena perbedaan waktu yang bersifat dinamis dan menyebar dalam ruang sehingga timbul kontras area terang dan gelap sekaligus permainan bayangan dalam ruang.

- Connection with natural system

Pola ini menghubungkan interior dengan sistem alam yang sering berubah bertujuan untuk pengguna ruang dapat berinteraksi dengan alam.

- Biomorphic forms and patterns

Pola ini akan meniru bentuk alam dalam bentuk motif untuk elemen pengisi ruangannya. Bertujuan untuk menghadirkan suasana alam secara langsung.

- Material connection with nature 
Pola yang digunakan adalah material alami yang mengalami perubahan dari waktu ke waktu sehingga dapat merefleksikan lingkungannya.

- Complexity and order

Pola yang menerapkan bentuk simetri dan geometri yang berulah dengan sebuah skala yang bisa sama dan berbeda untuk individu lebih mudah memahami ruang.

- Prospect

Pola yang memberikan pandangan yang terbuka dan terang pada ruang agar pengguna dapat merasakan keanekaragaman ruang tersebut.

- Refuge

Pola yang membuat area tertutup atau membatasi pandangan dari luar agar pengguna merasa aman dari orang luar dan merasa terlindungi.

- Mystery

Pola ini memberikan rasa kagum akan sensasi yang dirasakan dalam ruang seperti sebuah pergerakan yang dinamis, dan perubahan waktu ke waktu dalam perasaan ruang.

- Risk and peril

Pola yang memberikan rasa bahaya atau ancaman tapi tetap akan berasa aman untuk melindungi pengguna ruang.

Pola biophilic design tidak dapat berdiri sendiri. Sehingga pola-pola dalam desain ini akan berhubungan satu sama lain yang bisa menciptakan bentuk desain yang terlihat mirip. Hal ini semua tergantung pada desainernya yang menekankan pola dalam menciptakan suasana ruang untuk menciptakan pengalaman ruang biophilia.

\section{Neuroarchitecture}

Penerapan neuroarchitecture ini diigunakan untuk mencoba mengubah pandangan terhadap sebuah pengalaman ruang, yang terlihat sama saja dengan keadaan lingkungan luar, yang bisa membuah perubahan pandangan seseorang. Neuroarchitecture sendiri merupakan sebuah hubungan antara Kesehatan dan pengalaman ruang. Dimana otak dan perasaan dapat mempengaruhi Kesehatan emosional pada seseorang.

\section{Hasil Perancangan}

Hasil dari perancangan berupa bangunan edukasi dan ruang publik sebagai media penyalur ilmu tentang hutan, dan interaksi antar makhluk hidup dengan alam, program tersebut muncul dari latar belakang deforestasi yang terjadi di daerah Kalimantan.

\section{DISKUSI DAN HASIL}

\section{Program}

Ruang edukasi ini sebagai sebuah media untuk bisa memberikan pengetahuan terhadap fungsi dari hutan untuk makhluk hidup. Karena di daerah Kalimantan menjadi salah satu dari banyaknya terjadi kasus deforestasi hutan di Indonesia, dan jika dibiarkan terus menerus maka akan bisa mengakibatkan kehilangan hutan yang lebih luas di Kalimantan yang bisa berdampak sangat besar bagi makhluk hidup. Mengapa ruang edukasi? karena dengan ruang edukasi bisa meningkatkan akan kesadaran masyarakat tentang menjaga hutan. 


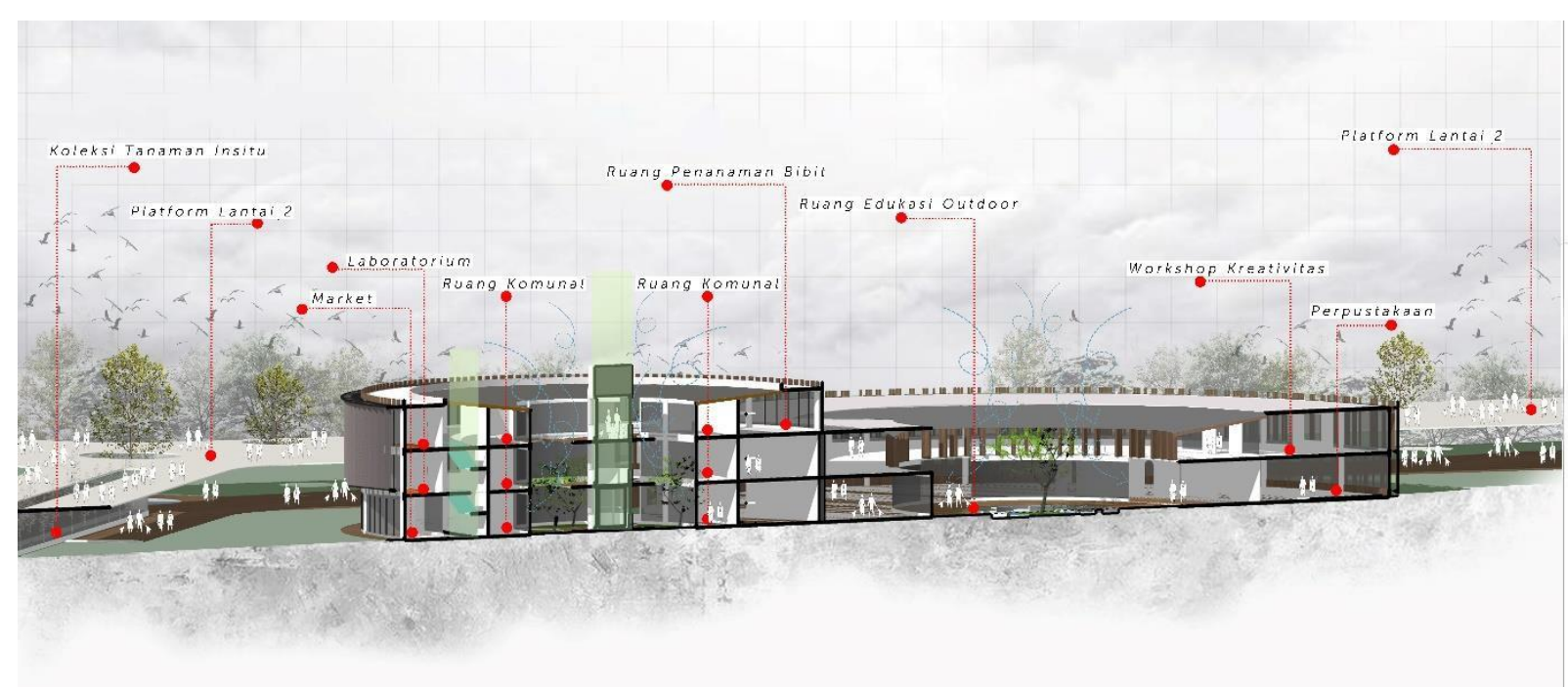

Gambar 1. Program Utama dan Fasilitas

Sumber: Penulis, 2021

\section{Tapak}

Tapak yang terpilih adalah di Kebun Raya Sampit dengan luas lahan sebesar 600ha yang berlokasi Kecamatan Telawang, Kabupaten Kotawaringin Timur, Kota Kalimantan Tengah. Di kawasan ini bisa dijadikan sebuah potensi baik dari segi pariwisata ataupun konservasi. Kebun raya sampit merupakan kebun raya yang masih dalam tahap perencanaan atau tahap awal dalam pembangunan sebuah kebun raya, dan mempunyai sebuah tema yaitu konservasi tumbuhan hutan kerangas.

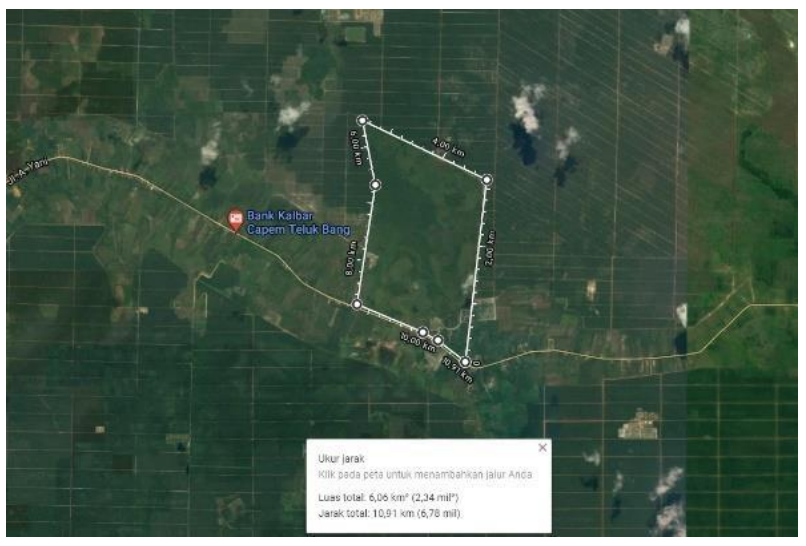

Gambar 2. Lokasi Tapak

Sumber: Google Maps

Dan zona yang terpilih adalah ada pada bagian depan dari Kebun Raya Sampit yang memiliki luas 9ha, sebagai referensi dari zoning Kebun Raya Bogor yang menjadikan area edukasi dan konservasi berada di bagian depan atau pintu masuk utama dari Kebun Raya Bogor tersebut.

Peraturan pembangunan pada kawasan Kebun Raya Sampit adalah sebagai berikut;

Tata guna lahan

KDB

$\mathrm{KDH}$

KLB

Lebar jalan utama
: Kebun raya

: $20-40 \%$

: 60\%

: 1-3

: $8 \mathrm{~m}$ 


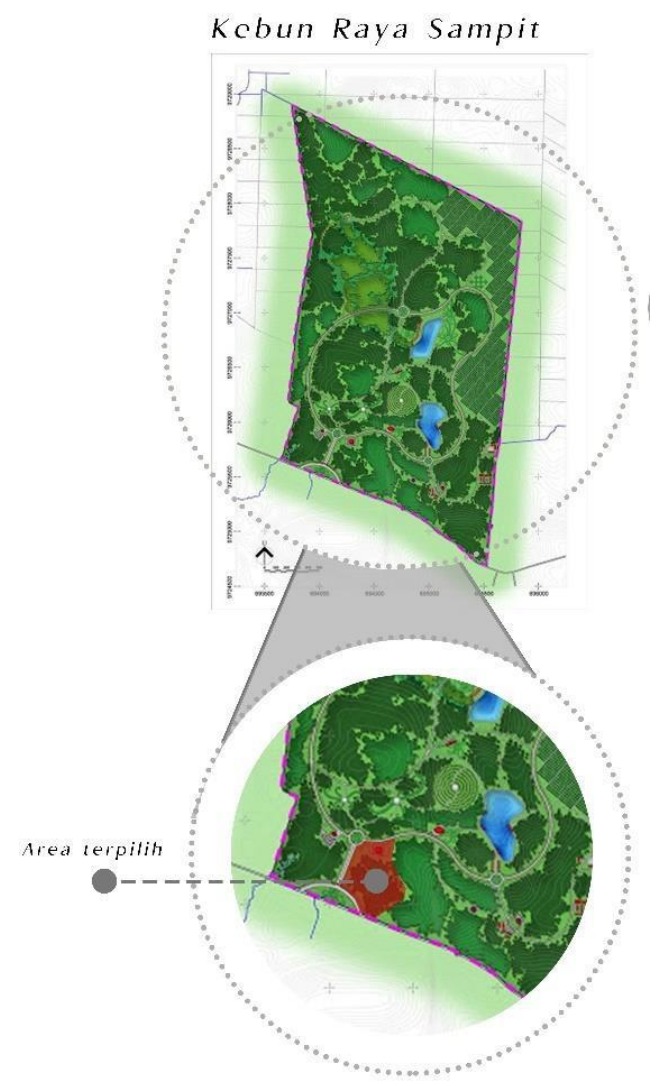

Gambar 3. Zona Terpilih

Sumber: Google Image

Pada akses utama terhadap Kebun Raya Sampit melalui Jl. Jenderal Sudirman yang bisa langsung menuju ke kota Sampit, dan disekeliling area tersebut masih terdapat luas untuk area hutan dan menjadi sebuah objek wisata pada area kebun raya yang bisa berpotensi untuk menarik pengunjung.

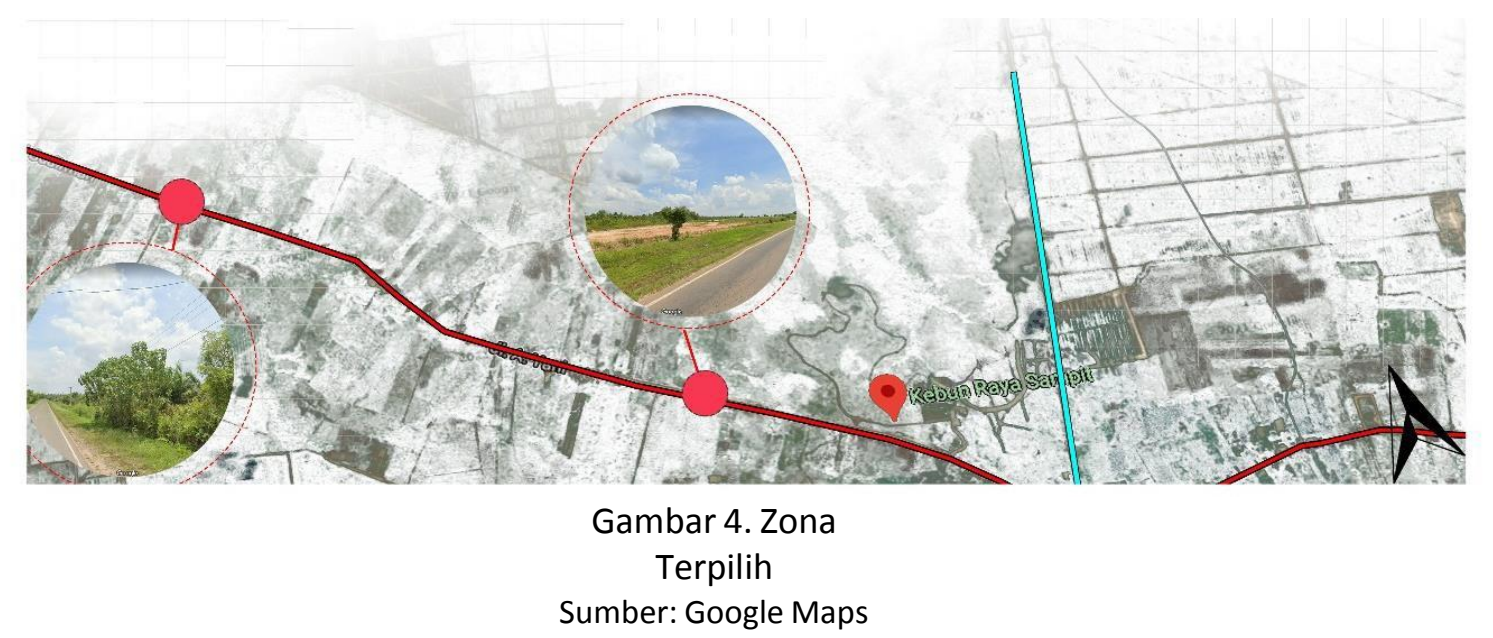

Keadaan hutan di sekitar Kawasan Kebun Raya Sampit masih sangat dominan di banding dengan area pemukiman di sekitarnya. Dan untuk area pemukiman hanya terdepat beberapa titik saja yang membuat daerah tersebut masih sangat terjaga dalam hal kelestarian hutannya. 


\section{Konsep}

Desain dirancang terhadap analisis yang sebelumnya. Dengan membuat ruang edukasi menjadi program utama yang menunjang beberapa program lainnya. Dan pada dasarnya fungsi pada bangunan ini adalah untuk wadah bagi masyarakat saling berinteraksi dan mendapatkan ilmu. Untuk mewujudkan tujuan dari ruang edukasi ini pengunjung bisa merasakan di dalam bangunan utama untuk bisa melalukan sebuah kegiatan seperti membaca, melihat keindahan dan kerusakan hutan melalui sebuah exhibiton, meneliti tanaman, dan mengerti bagaimana cara melestarikan tanaman, dan pengunjung bisa merasakan dan melihat masa depan jika hutan tetap dijaga dan dilestarikan dengan baik.
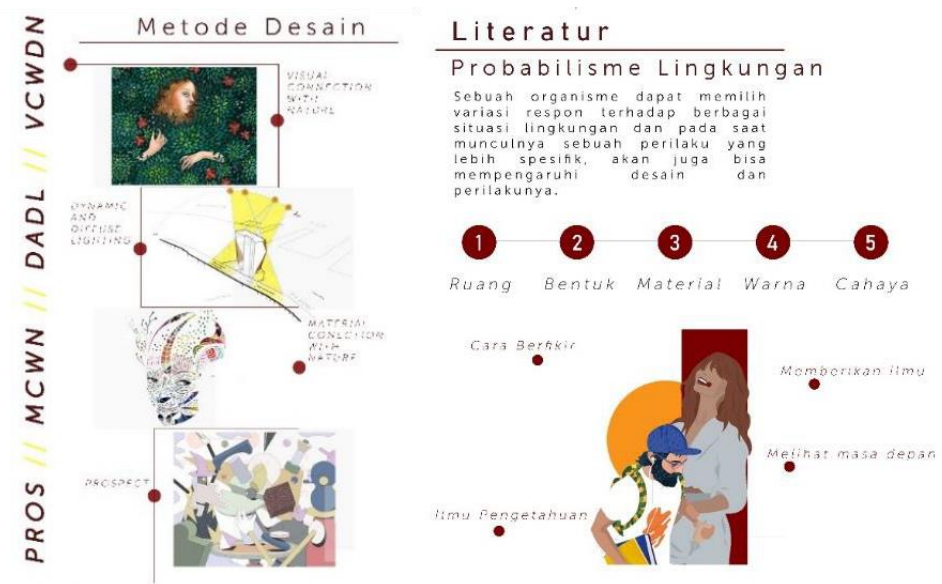

Gambar 5. Proses Konsep dengan Metode Desain Sumber: Penulis, 2021

Untuk mewujudkan sebuah konsep pada proyek ini adalah pada gubahan masa utama yang membentuk 3 lingkaran yang di gabung dengan di latar belakangi dari permasalahan diatas, dan bisa untuk memberikan sebuah gambaran untuk saling memberi kehidupan bagi seluruh makhluk hidup dari manusia, tumbuhan, dan binatang yang harus saling bekerja sama dan saling memikirkan kepentingan bersama tidak hanya memikirkan kepentingan individu seorang.

Untuk area sekeliling dari bangunan utama dibuat sebuah desain yang bertujuan untuk mencerminkan bumi di masa yang akan datang jika hutan hilang dari bumi ataupun tidak. Sekaligus bisa merasakan dampak baik dan buruk yang akan terjadi di masa yang akan datang.

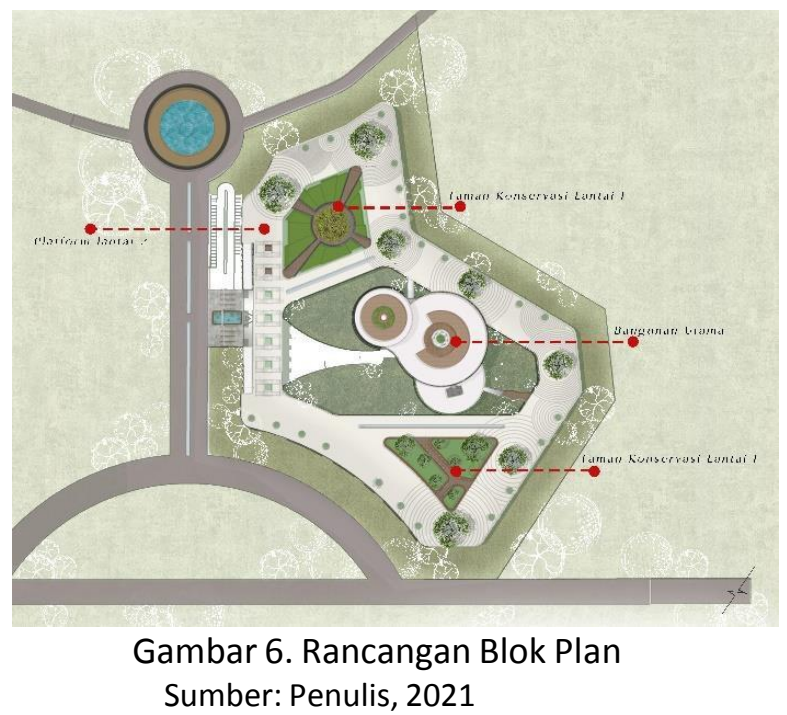


Pada platform lantai 2 dibuat secara terbuka dengan menempatkan beberapa titik pohon untuk menyejukan area dari panas matahari yang bertujuan untuk merasakan kondisi bumi jika terus menerus hutan di hilangkan untuk kepentingan pribadi tetapi tidak memikirkan makhluk hidup di hutan dan di sekitarnya. Sedangkan untuk lantai 1 di area taman konservasi dibuat secara tertutup dan terlindungi dari panas matahari dan menempatkan taman konservasi dengan pohon khas Kalimantan yaitu pohon ulin yang merupakan pohon terbesar di Indonesia, yang bertujuan untuk bisa merasakan kondisi bumi jika hutan tetap terjaga.

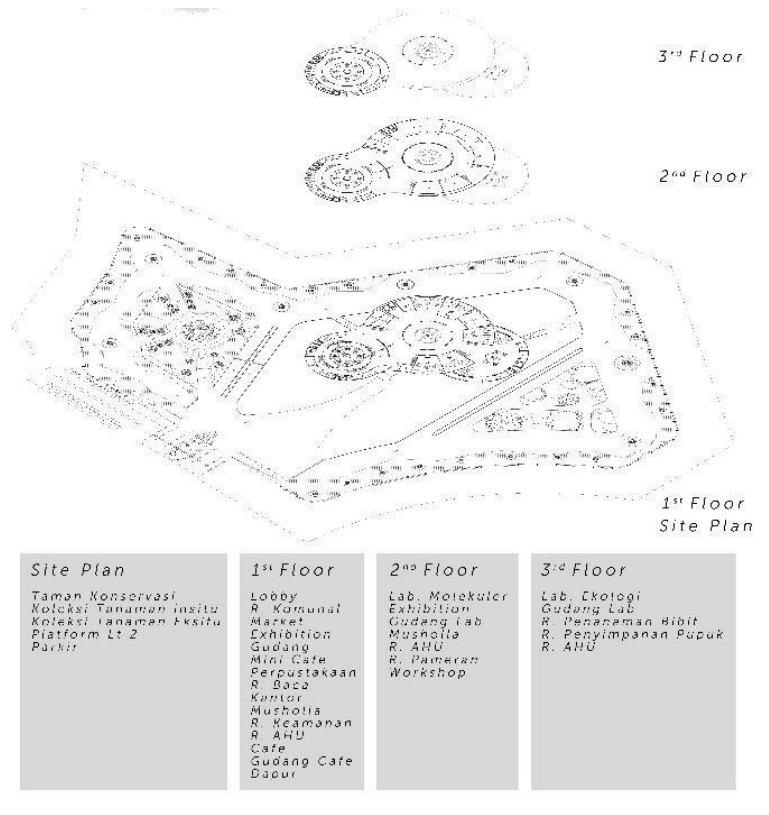

Gambar 7. Rancangan Denah

Sumber: Penulis, 2021

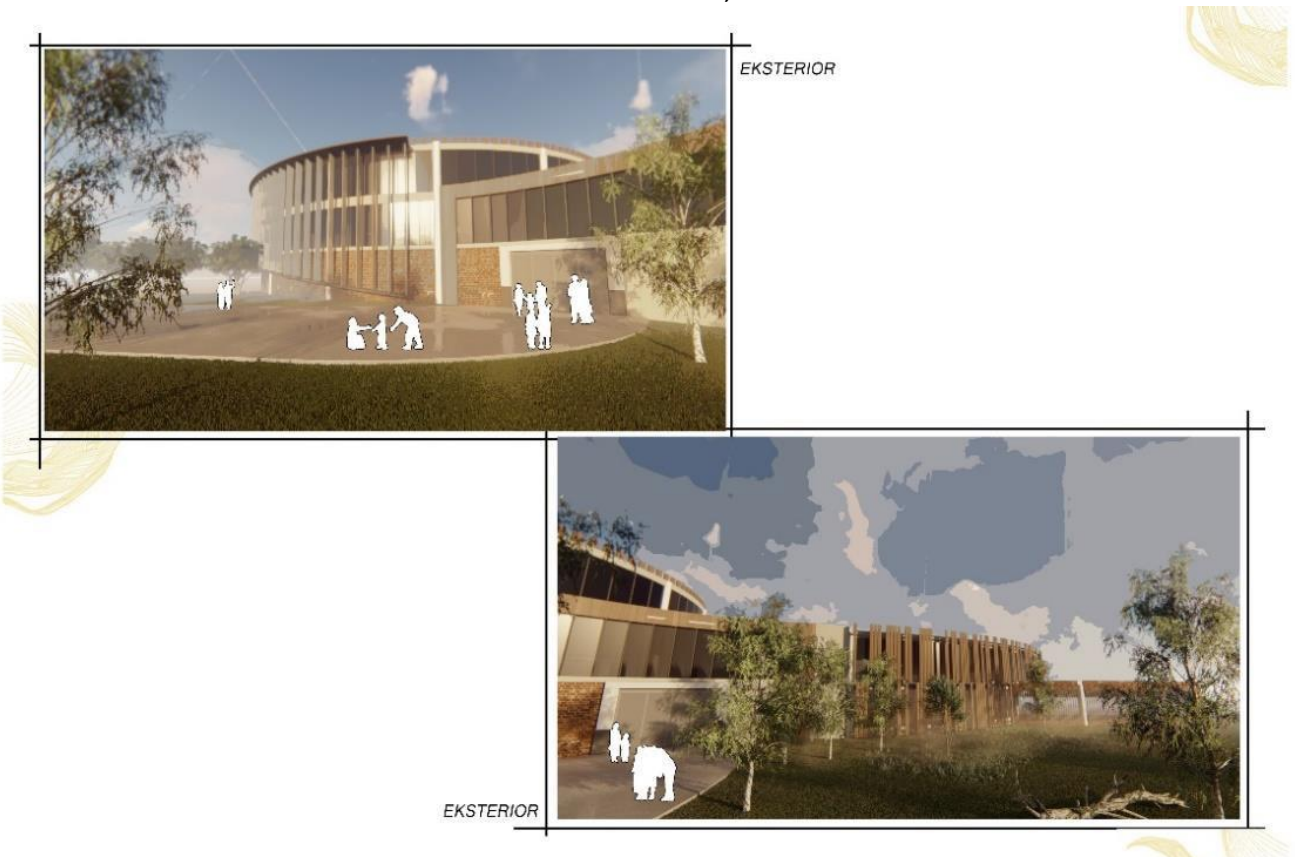

Gambar 8. Desain Ruang Edukasi Hutan

Sumber: Penulis, 2021 


\section{Kesimpulan dan Saran}

Untuk mengedukasi masyarakat mengenai sebuah ilmu dan informasi terhadap hutan yang lebih luas membutuhkan sebuah media yang lebih interaktif dan tidak melulu secara formal. Dan kurangnya pemanfaatan teknologi digital serta pemanfaatan lahan dari sebuah obyek wisata yang seharusnya bisa dimanfaatkan sebagai sebuah wadah untuk bisa memberikan ilmu kepada masyarakat tentang sebuah manfaat penting dari hutan sekaligus menjadikannya sarana edukasi dan rekreasi.

Konsep area edukasi yang digabungkan dengan teknologi digital dapat dirasakan di program utama tempat area masuk. Pengunjung akan merasakan lorong dengan ruang LED screen dan pada sambungan antara lingkaran terdapat area exhibiton digital dengan fitur seperti video dengan konsep yang kontekstual pada bangunan dan area sekitar.

Untuk mendapatkan sebuah ilmu mengenai hutan agar bisa menjaganya masyarakat harus bisa merasakan bagaimana dampak yang terjadi di dalam kehidupan hutan itu sendiri baik dari tumbuhan ataupun hewan. Maka dengan dibuatnya ruang edukasi hutan ini diharapkan masyarakat bisa merasakan dampaknya dan bisa lebih untuk menjaga kelestarian hutan dari tangan-tangan yang tidak bertanggung jawab yang sudah merusak hutan demi kepentingan individualnya.

\section{Referensi}

Abdul A. M., Ashadi, Anggana F. (2018). Konsep arsitektur ekologi pada penataan kawasan wisata candi cangkuang di garut, jawa barat. Jurnal Arsitektur PURWARUPA. 2(2), September 2018

Almusaed, A. (2011). Biophilic and Bioclimatic Architeture "Analytical Therapy for the Next Generation of Passive Sustainable Architecture. Denmark: Authors

Holvey, C. (2016, Desember 16). https://www.bbc.com/Indonesia/vert-earth38375353. http://arsitektur-Indonesia.com/arsitektur/arsitektur-dan-lingkungan/. (n.d.).

Miller, G. Tyler. Dan Spoolman, Scott E. Essentials of Ecology. USA; Brooks/Cole,2009.

Nudwi. (2011). /Ekowisata sebagai upaya pembangunan ekonomi/ (http://nudwi.wordpress.com/2011/06 /29/ekowisata-sebagai-upaya-pembangunanekonomi/, diakses 13 Juli 2021)

Ramadhani, M. (2020). Perancangan resort di Malabero Bengkulu dengan Penampilan vernakular bengkulu dan pendekatan biormorfik/. Laporan akhir sarjana, 10-12.

Septyan, A. R. (2019, April 2). https://foresteract.com/deforestasi/.

Supardjo, S. (2014). Aplikasi arsitektur biormorfik dalam rancangan arsitektur, Jurnal Media Matrasain, Jurusan Arsitektur, FT-UNSRAT, Vol 11, No 1, Mei 2018 